\title{
PENGARUH MODEL PEMBELAJARAN NUMBERED HEADS TOGETHER TERHADAP HASIL BELAJAR SISWA PADA MATA PELAJARAN PPKn SISWA KELAS VIII DI SMP SWASTA CITRA HARAPAN PERCUT SEITUAN
}

\author{
Zulmawati \\ STKIP Riama Medan \\ Email: zulma.wati@gmail.com
}

\begin{abstract}
ABSTRAK
Penelitian ini bertujuan untuk mengetahui pengaruh model pembelajaran kooperatif numbered heads together terhadap hasil belajar PPKn siswa pada materi Sumpah pemuda dalam bingkai Bhinneka Tunggal Ika di kelas VIII SMP Swasta Citra Harapan Percut Seituan. Jenis penelitian ini adalah penelitian Tindakan Kealas ( PTK ). Subjek dalam penelitian ini adalah siswa kelas VIII sebanyak 30 orang . Tujuannya adalah untuk meningkatkan hasil belajar siswa dengan menggunakan model koperatif numbered heads together. Dari analisis hasil studi tentang pembelajaran yang diperoleh melalui pengamatan kegiatan guru dan siswa dikategorikan baik, dan hasil pembelajaran siswa telah diselesaikan baik secara individu dan klasikal. Pada siklus I hasil ketuntasan yang dicapai yaitu $63 \%$, karena belum mencapai hasil ketuntasan yang efektif secara klasikal yaitu $\geq 85 \%$ maka dilanjutkan ke siklus II dan diperoleh hasil ketuntasan klasikal sebesar $90 \%$ atau meningkat $27 \%$ Dengan demikian implementasi pembelajaran menggunakan model numbered heads together untuk materi sumpah pemuda dalam bingkai bhinneka tunggal ika dikelas VIII mempunyai pengaruh sehingga meningkatkan dan mempengaruhi hasil belajar siswa
\end{abstract}

\section{Kata kunci : Model pembelajaran Numbered Heads Together, Hasil belajar}

\begin{abstract}
This study aims to determine the effect of the numbered heads together cooperative learning model on student Civics learning outcomes on the subject of the Youth Pledge within the Bhinneka Tunggal Ika frame in class VIII Citra Harapan Private Junior High School Percut Seituan. This type of research is Classroom Action Research (CAR). The subjects in this study were 30 grade VIII students . The aim is to improve student learning outcomes by using the numbered heads together cooperative model. From the analysis of the results of studies on learning obtained

p-ISSN 2648-8600

e-ISSN 2745-410X

Volume 4 Nomor 1 Juni 2021


through observations of teacher and student activities, it is categorized as good, and student learning outcomes have been completed both individually and classically. In the first cycle, the mastery result achieved is $63 \%$, because it has not achieved the classically effective completeness result, which is $\geq 85 \%$, then proceed to the second cycle and the classical mastery result is $90 \%$ or an increase of $27 \%$. Thus, the implementation of learning uses the numbered heads together model. for the youth oath material in the Bhinneka Tunggal Ika frame in class VIII has an influence so that it increases and affects student learning outcomes hasil

\section{Keywords: Numbered Heads Together learning model, learning outcomes}

\section{Latar belakang masalah}

Pendidikan merupakan usaha sadar dan terencana untuk mewujudkan suasana belajar dan proses pembelajaran agar siswa secara aktif mengembangkan potensi dirinya untuk memiliki kekuatan spiritual keagamaan, pengendalian diri, kepribadian, kecerdasan, akhlak mulia serta keterampilan yang diperlukan dirinya, masyarakat, bangsa, dan negara. Salah satu lembaga pendidikan adalah sekolah. Sekolah merupakan lembaga pendidikan yang mempunyai tugas untuk mengembangkan segala potensi yang dimiliki siswa. Pengembangan potensi yang dimiliki masing-masing siswa dengan optimal akan meningkatkan taraf kehidupan kelak.
Sekolah sebagai lembaga pendidikan, sarana dan prasarana bagi siswa untuk menimba ilmu,mengubah prilaku siswa. Lemahnya proses pembelajaran merupakan salah satu masalah yang dihadapi dunia pendidikan saat ini. Hasil belajar belum mencapai Kriteria Ketuntasan Maksimum ( KKM ). Siswa kurang terampil dalam menyampaikan gagasan/ pendapatnya sendiri dan para gurupun kurang efektif dalam menggunakan model dan dipihak siswapun menganggap pelajaran pendidikan pancasila dan kewarganegaraan kurang menyenangkan dan merupakan hafalan yang sulit dimengerti

PPKn merupakan ilmu sosial yang kurang diminati dan biasanya hanya berpusat pada guru/ ceramah 
Dengan belajar PPKn diharapkan dapat meningkatkan kemampuan siswa dalam beradaptasi dengan mengedepankan moral . Oleh karena itu, PPKn dipelajari mulai dari sekolah rendah (taman kanak-kanak) sampai pada perguruan tinggi. Peran penting PPKn dalam kehidupan seharusnya membuat PPKn menjadi mata pelajaran yang diminati dan menarik. Namun faktanya banyak siswa yang kurang menyukai PPKn karena dianggap tidak menarik. Siswa yang termotivasi dalam belajar cenderung menyukai pelajaran yang dipelajarinya sehingga ia akan mengupayakan kegiatan belajarnya semaksimal mungkin. Sudah seharusnya guru mendesain pembelajaran yang kooperatif yang melibatkan siswa secara aktif didalam pembahasan materi sehingga menaikan hasil belajat siswa

Hasil wawancara dengan guru bidang studi PPKn di SMP Swasta Citra Harapan Percut Seituan, mengatakan bahwa sangat banyak permasalahan yang dihadapi guru dalam melaksanakan pembelajarannya, seperti rendahnya hasil belajar siswa yang masih banyak dibawah Kriteria Ketuntasan Minimum ( KKM ) yaitu 75 sehingga hasil belajar siswa belum tuntas. Kurangnya kemampuan guru untuk mempergunakan model pembelajaran menjadi salah satu penyebab rendahnya hasil belajar siswa Dalam praktek guru sangat jarang menggunakan model yang bervariasi yang kerap mereka laksanakan hanya menggunakan metode ceramah Untuk itu perlu dicari suatu model pembelajaran yang berpusat pada aktifitas siswa sehingga menciptakan adanya interaksi yang baik antara guru dengan siswa.

\section{Data hasil belajar siswa}

\begin{tabular}{|c|c|c|c|c|c|}
\hline $\begin{array}{l}\text { Tahun } \\
\text { Pelajaran }\end{array}$ & $\begin{array}{l}\text { KK } \\
\text { M }\end{array}$ & $\begin{array}{l}\text { Jumla } \\
\text { h } \\
\text { siswa }\end{array}$ & $\begin{array}{l}\text { Jumla } \\
\text { h } \\
\text { siswa } \\
\text { tuntas }\end{array}$ & $\begin{array}{l}\text { Jumla } \\
\text { h } \\
\text { siswa } \\
\text { tidak } \\
\text { tuntas }\end{array}$ & $\begin{array}{l}\text { Nila } \\
\mathrm{i} \\
\text { rata } \\
- \\
\text { rata }\end{array}$ \\
\hline $\begin{array}{l}2020 / 202 \\
1\end{array}$ & 75 & 30 & $\begin{array}{l}17 \quad( \\
57 \%)\end{array}$ & $\begin{array}{l}13( \\
43 \%)\end{array}$ & 71 \\
\hline
\end{tabular}

PPKn SMP Swasta Citra Harapan Percut Seituan )

\section{Kajian Pustaka}




\subsection{Pengertian Belajar}

Belajar merupakan sesuatu yang harus kita alami di dalam kehidupan, dan akan berlangsung secara terusmenerus.

Hilgrad dan Bower dalam Baharuddin dan Wahyuni (2015:15) menyatakan Belajar adalah memperoleh pengetahuan atau menguasai pengetahuan melalui pengalaman mengingat,, menguasai pengalaman dan mendapatkan informasi atau menemukan

Menurut Sujana ( 2009:2) Belajar merupakan suatu proses yang ditandai adanya perubahan tingkah laku pada diri seseorang.Oleh karenanya belajar itu bisa dikatakan sebagai suatu proses perubahan tingkah laku yang bersifat menetap pada diri seseorang yang didapat dari adanya interaksi, respon dan latihan khusus.

\section{2 .Hasil Belajar}

Hasil belajar menurut Oemar hamalik (2006:30) "Hasil belajar adalah bila seseorang telah belajar akan terjadi perubahan tingkah laku pada orang tersebut misalnya dari tidaka tahu menjadi tahu dan tidak mengerti menjadi mengerti. Arikunto (1990"133) mengatakan hasil belajar adalah hasil akhir setelah mengalami proses belajar, perubahan itu tampak dalam perbuatan yang dapat diamati dan diukur .selanjutnya menurut Sujana (2009:3) "Hasil belajar siswa pada hakekatnya adalah Perubahan tingkah laku" Tingkah laku yang dimaksudkan sebagai hasil belajar dalam pengertian luas mencakup bidang kognitif,efektif dan psikomotorik. Oleh karenanya belajar dan hasil belajaradalah dua hal yang tidak bisa dipisahkan karena hasil belajar akan dicapai melalui usaha yang dilakukan dalam belajar itu sendiri.

\subsection{Pengertian Model Pembelajaran}

Model pembelajaran adalah kerangka konseptual yang melukiskan prosedur yang sistematis dalam memgorganisasikan pengalaman belajar untuk mencapai tujuan belajar tertentu dan berfungsi sebagai pedoman bagi para perancang pembelajaran dan para pengajar dalam merencanakan 
aktifitas belajar mengajar. Menurut

Rianto (2009)"pembelajaran kooperatif adalah model pembelajaran yang dirancang untuk membelajarkan kecakapan akademik (Academic Skill), sekaligus keterampilan sosial (Sosial Skill) termasuk interpersonal skill”. Artzt dan Newman (dalam Trianto,2012) menyatakan bahwa "pembelajaran kooperatif adalah kondisi siswa belajar bersama sebagai suatu tim dalam menyelesaikan tugastugas kelompok untuk mencapai tujuan bersama dan setiap anggota kelompok memiliki tanggung jawab yang sama untuk keberhasilan kelompoknya

\subsection{Model Pembelajaran Numbered}

Heads Together (NHT)

Menurut Ibrahim ( 2000:22) Model NHT adalah bagian dari model pembelajaran kooperatif structural nyang menekankan pada strukturstruktur khusus khusus yang dirancang untuk mempengaruhi pola interaksi siswa .Menurut Anita Lie (2010:59)" Tekhnik beljar mengajar kepala bernomor Numbered Heads Together merupakan tekhnik memberikan kesempatan kepada siswa untuk saling membagikan ide-ideatau gagasan dan mempertimbangkan jawaban yang paling tepat. Selain itu tekhnik ini dapat digunakan dalam semua mata pelajaran dan semua tingkatan usia peserta didik"

Numbered head together (NHT) adalah suatu model pembelajaran berkelompok yang setiap anggota kelompoknya bertanggung jawab atas tugas kelompoknya, sehingga tidak ada pemisahan antara siswa yang satu dengan siswa yang lain dalam suatu kelompok untuk saling memberi dan menerima antara satu dengan yang lain. Model Numbered Head Together penyampaian materi dengan menggunakan kelompok sebagai wadah dalam menyatukan persepsi/ pikiran siswa terhadap pertanyaan yang dilontarkan atau yang diajukan guru yang kemudian akan dipertanggungjawabkan oleh siswa sesuai dengan nomor permintaan guru dari masing-masing kelompok. Dengan demikian dalam kelompok siswa diberi nomor masing-masing sesuai dengan urutannya. Pembelajaran 
model kepala bernomor diawali dengan memberi nomor. Guru membagi kelas menjadi kelompok kecil. Jika jumlah siswa dalam satu kelas terdiri dari 30 orang dan akan dibagi menjadi 5 kelompok. Berdasarkan jumlah konsep yang dipelajari, maka tiap kelompok terdiri dari 6 siswa tiap-tiap orang dalam tiap-tiap kelompok diberi nomor 1-6 setelah kelompok terbentuk guru mengajukan beberapa pertanyaan yang harus dijawab oleh tiap-tiap kelompok berikan kesempatan pada tiap-tiap kelompok untuk menemukan jawaban. Pada kesempatan ini tiap-tiap kelompok menyatukan kepalanya "Head Together" berdiskusi memikirkan jawaban atas pertanyaan dari guru. Langkah berikutnya guru memanggil siswa yang memiliki nomor yang sama dari tiap-tiap kelompok, mereka diberi kesempatan memberi jawaban atas pertanyaan yang telah diterimanya dari guru, hal ini dilakukan terus sehingga siswa dengan nomor yang sama dari masing-masing kelompok memaparkan jawaban atas pertanyaan guru. Berdasarkan jawaban itu guru dapat mengembangkan diskusi lebih dalam sehingga siswa dapat menemukan jawaban pertanyaan tersebut, sebagai pengetahuan yang utuh.

\section{Metode penelitian}

Penelitian ini dilakukan dengan menggunakan Penelitian Tindakan kelas dengan tujuan untuk menaikan hasil belajar siswa. Dilaksanakan di SMP Swasta Citra Harapan Percut Seituan Subjek penelitian yang diambil adalah siswa kelas VIII SMP Swasta Citra Harapan Percut Seituan sebanyak 30 siswa. Objek penelitian ini adalah perbaikan pembelajaran dengan menggunakan model koperatif Numbered Heads Together untuk meningkatkan hasil belajar siswa pada mata pelajaran PPKn dengan materi Sumpah pemuda dalam bingkai Bhineka Tunggal Ika

\subsection{Prosedur penelitian}

Prosedur penelitian ini merupakan penelitian tindakan kelas (PTK ) yang dilaksanakan dengan mengikuti prosedur berdasarkan arikunto (2010:75) yang mencakup kegiatan perencanaan ( planning ), Tindakan ( 
Action ), Observasi ( Observation ), Refleksi ( Reflektion) dan Evaluasi ( Evaluation ).kelima kegiatan ini berlangsung secara berulang dalam bentuk siklus

\subsection{Analisis Data}

\section{Hasil belajar siswa}

\section{A, Ketuntasan individu}

Trianto (2012:241) merumuskan ketuntasan belajar siswa (individu) sebagai berikut :

$\mathrm{KB}=\mathrm{T} / \mathrm{Tt} \quad \mathrm{x} \quad 100 \% \ldots . . .($ Trianto 2012:241)

Keterangan $\mathrm{KB}=$ Ketuntasan belajar

$$
\mathrm{T}=\text { Jumlah skor yang }
$$

diperoleh siswa

$$
\mathrm{Tt}=\text { Jumlah skor total }
$$

Setiap siswa dikatakan sudah tuntas belajarnya ( ketuntasan individu ) jika proporsi jawaban benar siswa telah mencapai KKM yang telah ditetapkan yaitu 75

\section{B. Ketuntasan Klasikal}

$\mathrm{P}=\sum$ siswa yang tuntas $/ \sum$ siswa $\mathrm{x}$ 100\%...... (Zainal Aqib dkk .2011:41)

Keterangan $\mathrm{P}=$ persentase

Suatu kelas dinyatakan tuntas belajarnya ( ketuntasan klasikal) jika dalam kelas tersebut terdapat $\geq 85$ siswa yang telah tuntas belajarnya dari nilai KKM yang telah ditetapkan sekolah yaitu 75

\section{Hasil Penelitian}

Dengan menggunakan model numberedhead together pada mata pelajaran PPKN materi Sumpah Pemuda dalam Bingkai Bhineka Tunggal Ika di Kelas VIII SMP Citra Harapan Percut Sei Tuan Tahun Pelajaran 2020/2021 berdasarkan ketuntasan belajar siswa secara individu dimana seorang siswa dikatakan tuntas belajar apabila telah mencapai Kriteria ketuntasan minimal (KKM ) 75. Jadi dari penelitian yang dilakukan hasil yang diperoleh masih banyak siswa yang belum tuntas secara individu. 
Setelah dirangkum hasil belajar siswa secara individu maka data tersebut dirangkumkan ketuntasan hasil belajar siswa secara klasikal siklus I dalam tabel berikut:

\begin{tabular}{|l|l|l|}
\hline Keterangan & \multicolumn{2}{|l|}{ Siklus I } \\
\hline & Hasil & Presentase \\
\hline Siswa Tuntas & 19 & $63 \%$ \\
\hline Siswa tidak Tuntas & 11 & $37 \%$ \\
\hline Jumlah siswa & 30 & $100 \%$ \\
\hline
\end{tabular}

$\mathrm{P}=\sum$ siswa yang tuntas $/ \sum$ siswa $\mathrm{x}$ $100 \%$

$19 / 30 \times 100 \%=63 \%$ (Siswa yang tuntas )

$\mathrm{P}=\sum$ siswa yang tuntas $/ \sum$ siswa $\mathrm{x}$ $100 \%$

$11 / 30 \times 100 \%=37 \%$ ( siswa yang tidak tuntas )

Dalam pelaksanaan di siklus I hasil yang didapat pada pelaksanaan observasi kegiatan guru kategori baik sehingga peneliti mencari masalah yang menjadi penyebab pembelajaran belum mendapatkan hasil yang memuaskan dengan ketuntasan yang efektif secara klasikal harus mencapai $\geq$
$85 \%$ yang artinya hasil harus diperbaiki pada siklus berikutnya. Untuk lembar observasi kegiatan guru berkategori baik yang perlu ditingkatkan adalah menyampaikan topic/materi pembelajaran, pengelolaan kelas, penggunaan model numbered head together sesuai dengan kegiatan inti pembelajaran. Setelah dirangkum hasil belajar ketuntasan siswa secara klasikal pada siklus I diatas maka selanjutnya dirangkumkan ketuntasan hasil belajar siswa secara klasikal pada siklus II. Adapun data ketuntasan Hasil belajar siswa secara klasikal pada siklus II dapat kita lihat pada table berikut:

\begin{tabular}{|l|l|l|}
\hline Keterangan & \multicolumn{2}{|l|}{ Siklus II } \\
\hline & Hasil & Presentase \\
\hline Siswa Tuntas & 27 & $90 \%$ \\
\hline Siswa tidak Tuntas & 3 & $10 \%$ \\
\hline Jumlah siswa & 30 & $100 \%$ \\
\hline
\end{tabular}

$\mathrm{P}=\sum$ siswa yang tuntas $/ \sum$ siswa $\mathrm{x}$ $100 \%$

$27 / 30 \times 100 \%=90 \%$ ( siswa yang tuntas )

$\mathrm{P}=\sum$ siswa yang tuntas $/ \sum$ siswa $\mathrm{x}$ $100 \%$ 
$3 / 30 \times 100 \%=10 \%$ ( siswa yang tidak tuntas )

\section{Simpulan}

Kesimpulan yang dapat diambil dari hasil perbaikan pembelajaran yang dilaksanakan di Kelas VIII di SMP Citra Harapan Percut Sei Tuan Tahun Pelajaran 2020/2021 sebanyak 30 siswa yang menjadi subyek PTK dengan menggunakan model NumberedHead Together dalam materi Sumpah Pemuda dalam Bingkai Bhineka Tunggal Ika diperoleh Hasil sebagai berikut:

1. Hasil belajar siswa pada siklus I yaitu siswa yang tuntas sebanyak 19 siswa dari 30 siswa yang ada. Hal ini berarti secara klasikal yang tuntas hanya $63 \%$ sedangkan untuk memenuhi ketuntasan yang efektif secara klasikal harus mencapai $\geq 85 \%$ sehingga dapat dikatakan hasil pada siklus I hasil belajar siswa belum tuntas secara klasikal.

2. Pada siklus II hasil belajar siswa yang telah tuntas adalah sebanyak 27 siswa (90\%) dari 30 siswa yang ada, berarti secara klasikal hasil belajar siswa telah mencapai $90 \%$ dan dapat disimpulkan pada siklus II penerapan model belajar numberedhead together pada materi Sumpah Pemuda dalam bingkai Bhineka Tunggal Ika Kelas VIII SMP Citra Harapan Kec. Percut Sei Tuan Tahun pembelajaran 2020/2021 telah tuntas secara individu dan secara klasikal.

\section{DAFTAR PUSTAKA}

Anita Lie 2010. Cooperative learning. Jakarta: Gramedia

Arikunto Suharsimi. 2010. Penelitian Tindakan Kelas. Jakarta: Bumi Aksara Arikunto Suharsismi 1990.Prosedur penelitian suatu pendekatan praktis. Jakarta : Rieneka Cipta

Baharuddin dan Wahyuni . 2015.Teori belajar dan pembelajaran. Ar Ruzz : Media 
Ibrahim dkk.2000. Pembelajaran

kooperatif.Surabaya:University Press

Oemar hamalik 2006. Proses belajar

mengajar. Bandung: Bumi aksara

Rianto .2009.Aplikasi metode

penelitian.Yogjakarta: Nuha Medica

Sudjana, Nana 2009. Penilaian hasil proses belajr mengajar. Bandung :

Remaja Rosdakarya

Trianto.2012. Mendesain model

pembelajaran inovatif progresif.

Jakarta: Kencana prenada group

Zainal, Aqib dkk. 2011. Penelitian Tindakan Kelas untuk Guru SD, SMP, SMA. Bandung: Yrama Widya 